Chirurgia (2019) 114: 126-130

No. 1, January - February

Copyright@ Celsius

http://dx.doi.org/10.21614/chirurgia.114.1.126

\title{
Appendiceal Mass - Dilemmas Regarding Extension of the Resection
}

\author{
Daniel Ion ${ }^{1,2}$, Mihai Bogdan Serban', Dan Nicolae Paduraru', ${ }^{1,2}$, Adriana Elena Nica ${ }^{1,2}$, Al-Moushaly Rahim², \\ Octavian Andronic ${ }^{1,2}$
}

'The University of Medicine and Pharmacy "Carol Davila", Bucharest, Romania

${ }^{2} 3^{\text {rd }}$ Department of General Surgery, University Emergency Hospital Bucharest, Romania

Corresponding author:

Dan Nicolae Păduraru, MD

The University of Medicine and

Pharmacy "Carol Davila", Bucharest

3rd Department of General Surgery

University Emergency Hospital

Bucharest, Romania

E-mail: dan.paduraru.nicolae@gmail.com

\section{Rezumat}

Tumoră apendiculară - dileme asupra extensiei rezecției

Pornind de la un caz tipic, încercăm să evidențiem principalele elemente critice atât în algoritmul de diagnostic, cât şi în cel terapeutic. Prezentăm un pacient în vârstă de 54 de ani, cunoscut cu steatoză hepatică şi microlitiază renală, supus unei ecografii în ambulatoriu, pe fondul disconfortului abdominal difuz, care arată prezența unei mase tumorale în fosa iliacă dreaptă.

Cuvinte cheie: mucocele apendicular, apendicectomie, tumoră apendiculară

\section{Abstract}

Starting from a typical case, we try to highlight the main critical elements, both in the diagnostic algorithm and in the therapeutic one. We hereby present a 54-year old patient, known with hepatic steatosis and renal microlithiasis, which undergoes an ultrasonography in ambulatory, on the background of unsystematised abdominal discomfort; the ultrasound reveals the presence of a tumoral mass in the right iliac fossa.

Key words: appendiceal mucocele, appendectomy, appendiceal mass 


\section{Introduction}

The appendicular tumours have a low proportion - less than $0.5 \%$ - as compared to all the tumours of the digestive tube (1), so that there is a large dispersion of the cases, the statistical studies being significantly rare.

Starting from a typical case, we try to highlight the main critical elements, both in the diagnostic algorithm and in the therapeutic one. In both directions, the attitude has changed significantly in the latest two decades, due to technological progress - the introduction on a large scale of ultrasonography and computed tomography scan, and also the use of laparoscopy, as a routine procedure, both in diagnosis and in treatment.

The classification of the mucinous appendicular neoplasm remains controversial; universally, there is multiple classification systems proposed, but none used. The same situation may be found in case of risk stratification, different terminologies being used (2).

\section{Case Report}

A 54-year old patient, known with hepatic steatosis and renal microlithiasis, undergoes an an ultrasonography in ambulatory, on the background of unsystematised abdominal discomfort (moderated diffuse pain, abdominal swelling), which has evolved in the latest 2-3 months; the ultrasound reveals the following: in the right iliac fossa, there is a segment of digestive tube which comes from the cecum and ends in "glove finger" at suprapubic level, with progressive dilation of the lumen and walls of approx. $5 \mathrm{~mm}$, with non-homogenous liquid contents, and with hyper-echogenic areas and septs inside, towards the distal pole; dimensions: 137/58 $\mathrm{mm}$; there is Doppler signal only at the wall level; minimum liquid reaction in the right iliac fossa, of 4-6 mm (Fig. 1).

The clinical exam upon hospitalisation does not reveal signs of peritoneal irritation or palpable masses. Bearing in mind the ultrasound-related suspicion of appendiceal mass, we perform a CT scan, which reveals: obvious



Figure 1. Ultrasound imaging: cecum and appendiceal mass

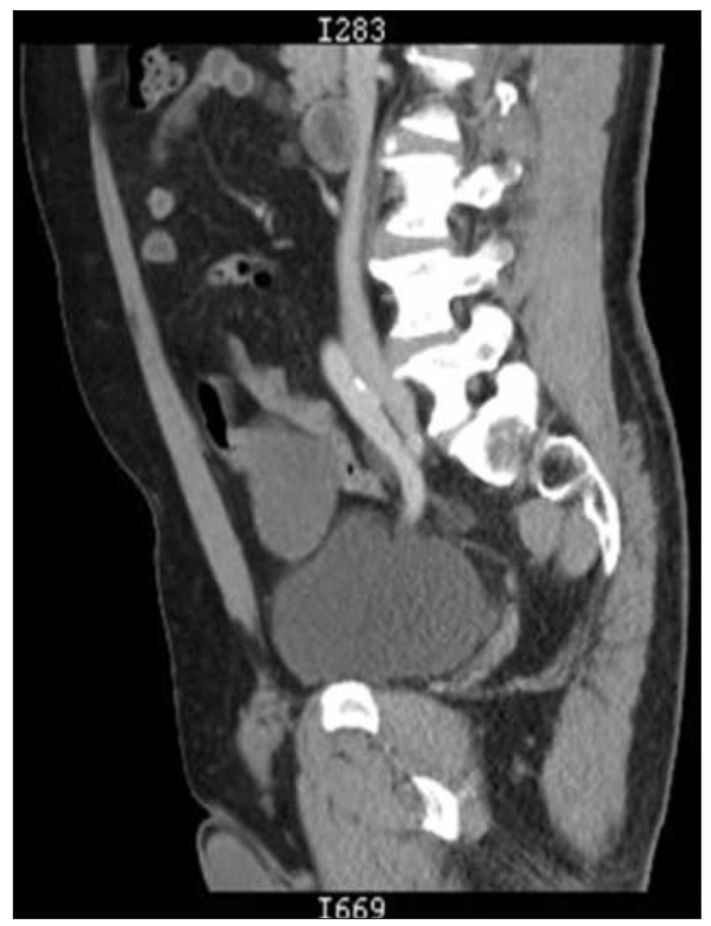

Figure 2. Computed Tomography Scan - sagittal section ( $x$ - appendiceal mass which imprints on the urinary bladder)

dilation with liquid contents $(17-19 \mathrm{UH})$ of the cecum appendix, axial diameters of $61 / 75 \mathrm{~mm}$; besides, there is an appendicolith, with the diameter of 10-14 mm (Figs. 2-4).

From the biological point of view, there is no inflammatory syndrome (WBC: $7400 / \mathrm{mL}, \mathrm{CRP}$ : $0.5 \mathrm{mg} / \mathrm{dL}$ ). The carcinoembryonic antigen is negative at the moment of hospitalisation.

We decide to perform laparoscopy, which confirms the presence of an appendiceal mass, without secondary peritoneal or hepatic determinations. 


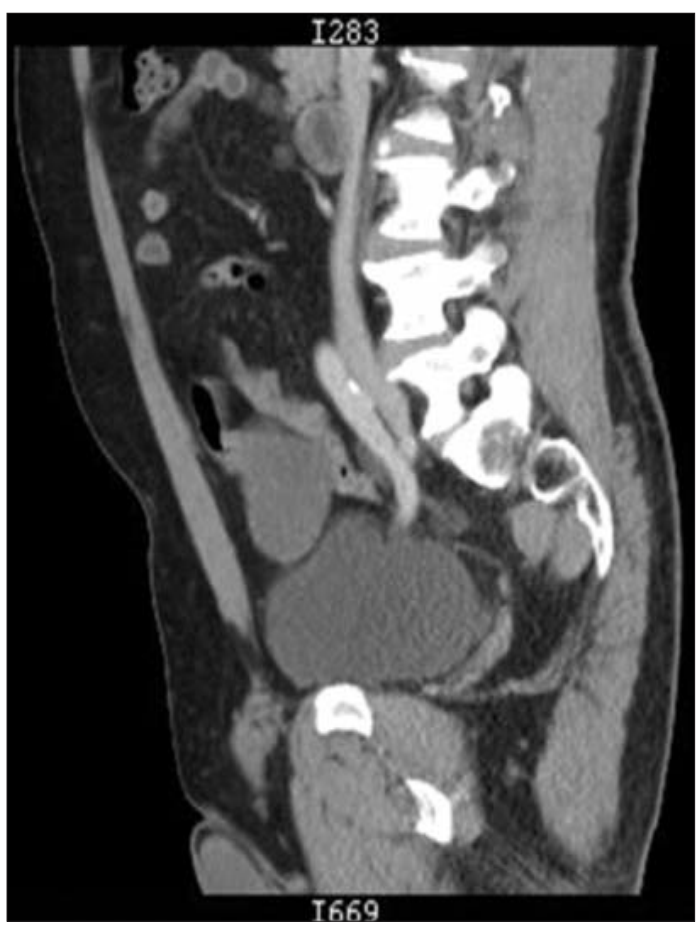

Figure 3. Computed Tomography Scan - sagittal section $(x-$ appendiceal mass)



Figure 4. Computed Tomography Scan - sagittal section ( $\mathrm{x}$ - appendiceal mass)

The peritoneal cytology performed on the lavage liquid is negative for neoplastic cells. We perform appendectomy, extracting the mass in the bag (Figs. 5-8).

Simple post-op evolution.

Macroscopically: the appendiceal mass, with dimensions of $10 / 5 / 3 \mathrm{~cm}$, cut in sagittal plan, has thin wall and mucinous gelatinous contents.

The microscopic exam at paraffin reveals: proliferation of low grade mucinous neo-

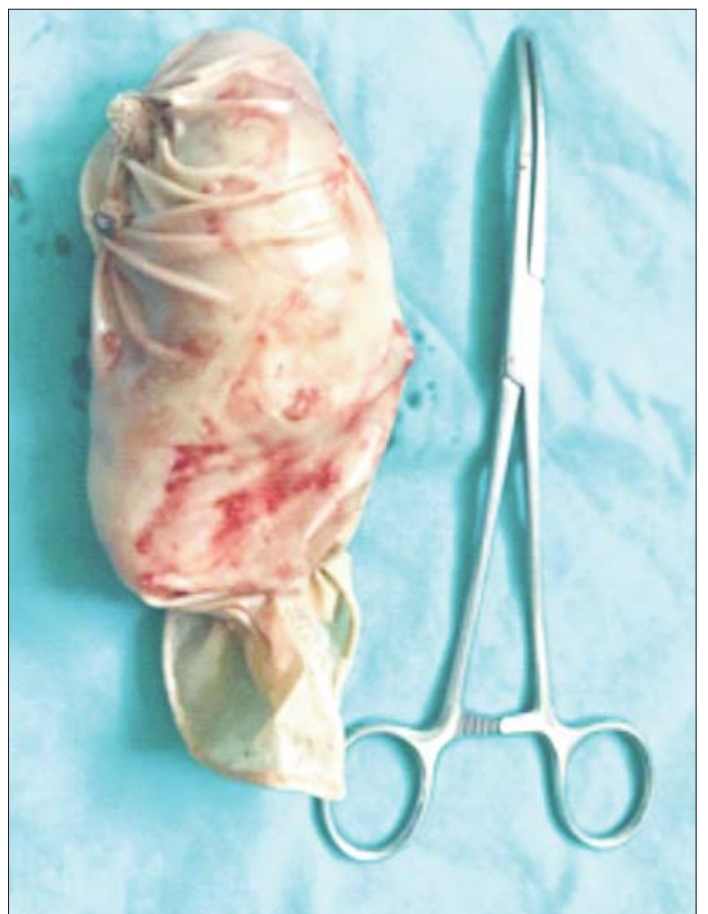

Figure 5. Appendiceal mass extracted in the bag

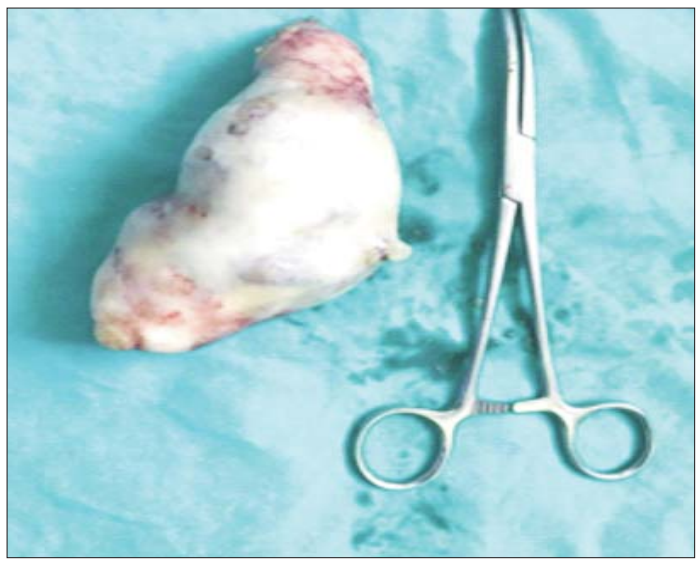

Figure 6. Extracted appendiceal mass

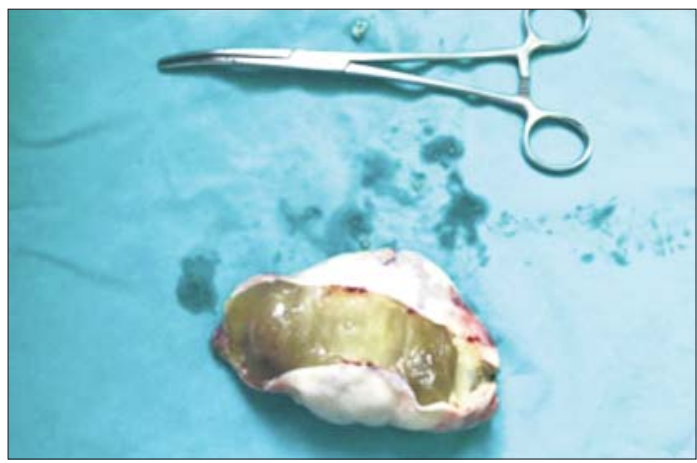

Figure 7. Extracted appendiceal mass 


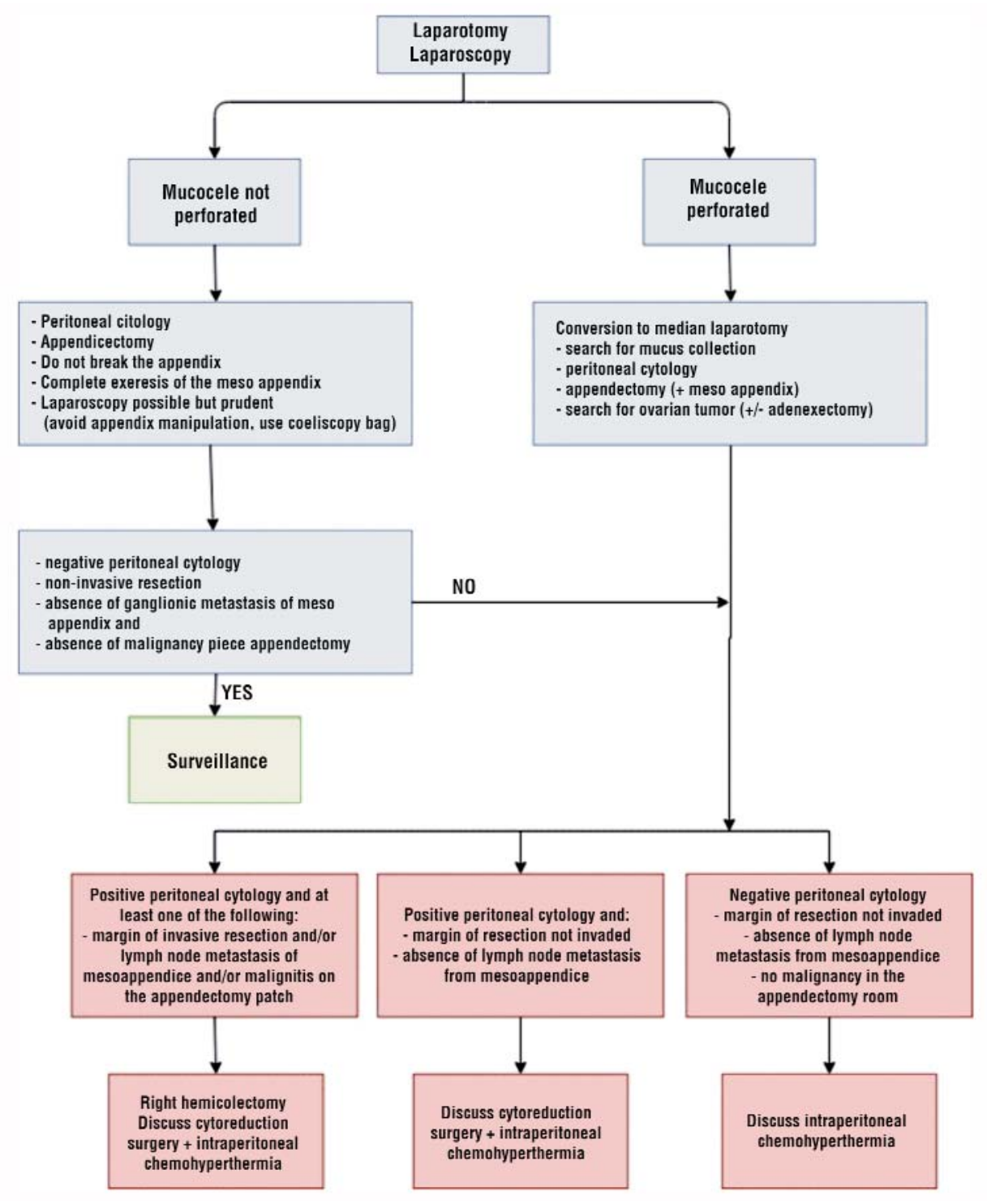

Figure 8. Algorithm for the management of the appendicealmucocele [after (6)]

plasm (LAMN) completely cut; no epithelial Discussions cells are seen in the mucus drops.

The immunohistochemical exam reveals: The abdominal ultrasound presents high negative AE1-AE3, negative CDX2, inconclusive MLH1, inconclusive MSH2, inconclusive MSH6, inconclusive PMS2.

The oncological exam recommends annual clinical, biological and imaging follow-up. The clinical and imaging follow-up in 6-month time and after one year, without signs of recurrence of metastases. resolution and accuracy, even for cavity organs, so that it must obligatorily include the examination of cecum-appendiceal region. The data from the scientific literature show that the ultrasonography of the appendix has good results in approx. $55 \%$ of the cases (3).

The laparoscopy, no matter the pathology that indicates it, must contain the cecumappendiceal region in the exploration stage. 
Table 1. Primary Appendiceal Neoplasm [after (4)]

\begin{tabular}{ll}
\hline Group & Description \\
\hline 1 & Mucinous Appendiceal Neoplasm; Non-ruptured \\
\hline 2 & Mucinous Appendiceal Neoplasm; Ruptured; \\
& LOW Risk recurrence \\
\hline 3 & Mucinous Appendiceal Neoplasm; Ruptured; \\
& HIGH Risk recurrence
\end{tabular}

The laparoscopic appendectomy in the appendicular mass shall be mandatorily preceded by lavage and peritoneal cytology. Positive cytology puts the tumour in the group 4, if Low Grade, and in the group 5, if High Grade (Table 1).

Subsequent to the histopathological exam, the examination of the muscularis mucosae is the central element in the identification of LAMN, this being intact in case of mucinous adenoma. The examination must contain the entire appendix in order to exclude extramucosal situation and to confirm the curative character of the procedure (5).

The attempts to correlate the immunohistochemical markers with the histological type and the prognosis have not given results, so that these cannot be used in making the therapeutic decision.

The assessment of the extension of the tumour to the cecum is made at two levels: at intra-op level, which may require hemicolecto- my on the right side, or at histopathologic level, and further re-intervention.

A technical detail which should not be neglected refers at the soft intra-operatory handling of the tumour and at its obligatory extraction in the bag.

Possible therapeutic directions may be synthesised using the algorithm - Fig. 8.

\section{Conclusions}

The appendicular mucocele remains a controversial pathology both diagnostically and therapeutically.Although the small incidence of this pathology makes difficult to carry out statistical studies, the publication of case series may lead to high-value conclusions.

\section{References}

1. Benedix F, Reimer A, Gastinger I, Mroczkowski P, Lippert H, Kube R. Primary appendiceal carcinoma-epidemiology, surgery and survival: results of a German multi-center study. Study Group Colon/Rectum Carcinoma Primary Tumor. Eur J SurgOncol. 2010;36(8):763-71.

2. Eze 0 , Jones R, Montgomery E. A practical approach for diagnosis of appendiceal mucinous neoplasms. Diagnostic Histopathology. 2017;23(12):530-35.

3. D'Souza N, D'Souza C, Grant D, Royston E, Farouk M. The value of ultrasonography in the diagnosis of appendicitis. International Journal of Surgery. 2015;13:165-69.

4. Cameron JL, Cameron AM. Current surgical therapy. Elsevier Health Sciences; 2012, p. 260.

5. Misdraji J. Mucinous epithelial neoplasms of the appendix and pseudomyxomaperitonei. Mod Pathol. 2015;28(suppl 1):S67-S79

6. Bosset JF, Conroy T, Dufour P. Referentiels regionaux de bonnes pratiques en cancerologie digestive. Oncolie. 2011 